\title{
Numerical Modeling of Pressure Source of Sinabung Volcano Based On GPS Data In 2011-2012 Using Particle Swarm Optimization (PSO)
}

\author{
Ratih Kumalasari ${ }^{1, a}$, Wahyu Srigutomo ${ }^{2}$, Irwan Meilano ${ }^{2}$ and Hendra \\ Gunawan $^{3}$ \\ ${ }^{1}$ Universitas Bhayangkara Jakarta Raya, Jl. Harsono Rm Dalam No.46 Ragunan Ps. Minggu \\ Kota Jakarta Selatan 12550, Indonesia \\ ${ }^{2}$ Institut Teknologi Bandung, Jl. Ganesa No. 10 Bandung 40132, Indonesia \\ ${ }^{3}$ Pusat Vulkanologi dan Mitigasi Bencana, Jl. Diponegoro No.57 Cihaur Geulis Bandung, \\ Indonesia \\ ${ }^{a}$ ratih.kumalasari@dsn.ubharajaya.ac.id
}

\begin{abstract}
Mogi Model with particle swarm optimization (PSO) scheme have been applied to the local GPS data of Sinabung Volcano during 2011 to 2012 to receive subsurface parameters as pressure sources in terms of misfit and inversion model parameter. The size of displacement was inverted by PSO. From the inversion concluded that the position pressure source showing shallow magma pockets at a depth between $\pm 1.3 \mathrm{~km}$ volume changes around $\pm 0.95 \times 10^{6} \mathrm{~m}^{3}$. It indicates the presence of a huge magma supply and continuous into shallow magma chamber up to the surface of Sinabung Volcano.
\end{abstract}

Keywords: Pressure source, PSO, Mogi Models, Sinabung

\section{Introduction}

Indonesian territory is located at the confluence of several tectonic plates involve the Eurasian Plate, the Indo-Australian Plate and the Pacific Plate. This position causes subduction activity so that many volcanoes are appeared in Indonesia, one of which is Sinabung Volcano. Sinabung Volcano is a strato type volcano that is administratively located in Karo Regency, North Sumatra Province, with a peak of $2,460 \mathrm{~m}$ above sea level, with coordinates $3^{\circ} 10^{\prime} \mathrm{LU}$ and $98^{\circ} 23.5^{\prime} \mathrm{BT}[1]$.

Before 2010 Sinabung Volcano was a type B volcano, which had not been erupted since 1600s, but still exposed volcanic activities such as the presence of solfatar or fumarole fields. The eruption activities of Sinabung Volcano have just been recorded since August 2010 which makes it as type A volcano. Later, continuous monitoring is done to mitigate the danger of the eruptions. Volcanic eruption activity is generally preceded by early symptoms or precursors, such as increased seismic activity, increased temperature of hot springs, changes in composition and strength of gas gusts, as well as the existence of deformations in the body of the volcano. Proper monitoring on the activities of a volcano requires input data from various methods, one of which is a deformation monitoring method by GPS data [2-4]. 


\section{Theoretical Background}

In this study we used the Mogi model (Point Pressure) [5], Mogi model (1958) assumes that the earth's crust is a semi-elastic medium and the deformation is caused by a point pressure at a certain depth. If there is a hydrostatic change in the ball, symmetrical deformation will occur. It is explained in the Volcano Deformation that the displacement on the surface caused by changes in hydrostatic pressure in the cavity of the earth's crust with a radius smaller than the depth $(a<<d)$ are stated in Equation 1 [6].

$$
\left(\begin{array}{c}
u \\
v \\
w
\end{array}\right)=\alpha^{3} \Delta P \frac{(1-v)}{G}\left(\begin{array}{c}
\frac{x}{R^{3}} \\
\frac{y}{R^{3}} \\
\frac{z}{R^{3}}
\end{array}\right)
$$

Where $d$ is the depth of the pressure source, $r$ is the radial distance of the pressure source to the monitoring point, $v$ is the poisons ratio, $G$ is the shear modulus, and $\Delta P$ is the change in pressure, as graphically illustrated in Figure 1.

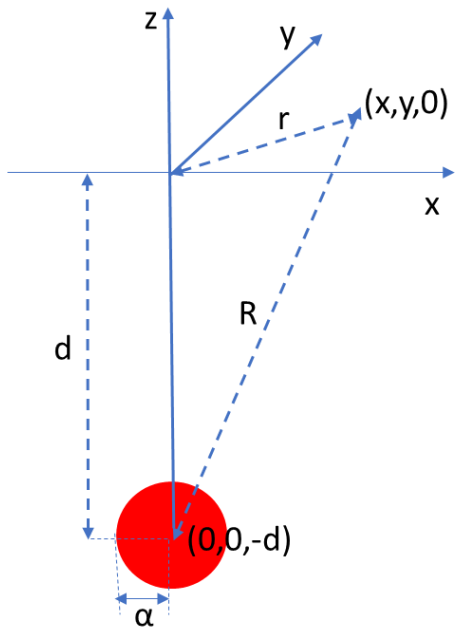

Figure 1. Mogi Model

\section{Materials and Methods}

The data that we used is devide into 2 period:

1. $1^{\text {st }}$ period (1st April $2011-22$ nd July 2011).

2. $2^{\text {nd }}$ period (22nd July 2011 - 4th March 2012).

Table 1. Changes of position in each period

\begin{tabular}{|c|c|c|c|c|c|c|c|c|}
\hline \multicolumn{2}{|c|}{ Period Station } & \multicolumn{3}{|c|}{ Coordinat } & \multicolumn{2}{|c|}{ displacement $(\mathrm{m})$} & \multicolumn{2}{|c|}{ Standard Deviation } \\
\hline & & $\mathrm{x}$ & $\mathrm{y}$ & $\mathrm{z}$ & $\begin{array}{ll}x & y\end{array}$ & $\mathrm{z}$ & $\mathrm{x}$ & $\mathrm{y}$ \\
\hline \multirow[t]{4}{*}{1} & & & 352794.03000 & & 0.00028 & 0.0161 & & 0.008830. \\
\hline & & & & & -0.0 & & 177 & 3182 \\
\hline & & & & & & & & \\
\hline & $3 G A$ & & 347 & & $\begin{array}{l}-0.006590 .0 \\
\end{array}$ & & 0.00906 & 10.02477 \\
\hline \multirow[t]{2}{*}{2} & & & 3527 & 1496. & $3-0.00072$ & 0.03 & 0.00912 & 540.02703 \\
\hline & KNL & 434757.39000 & 351034.5 & 1442.59190 & -0.000030 .00064 & 0.03238 & 0.01004 & 7280.02925 \\
\hline
\end{tabular}


Computational and Experimental Research in Materials and Renewable Energy (CERiMRE) Volume3, Issue2, page 75-81

eISSN : 2747-173X
Submitted : August 21, 2020

Accepted : October 11, 2020

Online : November 24, 2020

doi : $10.19184 /$ cerimre.v3i2.23549

\begin{tabular}{|c|c|c|c|c|c|c|c|}
\hline \multirow[t]{2}{*}{ Period Station } & \multicolumn{3}{|c|}{ Coordinat } & \multicolumn{2}{|c|}{ displacement $(\mathrm{m})$} & \multicolumn{2}{|c|}{ Standard Deviation } \\
\hline & $\mathrm{x}$ & $y$ & z & $\begin{array}{ll}x & y\end{array}$ & z & $\mathrm{x}$ & $y \quad z$ \\
\hline GRKI & 2671.64000 & 347790.79000 & 1230.30610 & $-0.00500-0.00053$ & 0.02528 & 0.00868 & 0.007080 .02702 \\
\hline SNBGA & 440477.08000 & 347201.59000 & 1248.57910 & $-0.00019-0.00027$ & 0.02590 & 0.00584 & 0.004530 .02537 \\
\hline
\end{tabular}

We use Particle Swarm Optimization (PSO) to characterize the pressure source parameters of Sinabung volcano. Particle Swarm Optimization (PSO) is an optimization algorithm that mimics the processes in the life survival of a flock of bird and a school of fish developed by James Kennedy and Russell Eberhart in 1995 [7-8]. In PSO, the population is assumed to be a particle with certain size and located at a random location in a multidimensional space. At the initial position of each particle is assumed to have two characteristics, namely position and speed. Each particle moves in a certain space and remembers the best position (pbest) that has ever been passed or found against food sources or the value of an objective function, each particle then conveys its information or best position to other particles and adjusts its position and speed based on information received regarding the best position (gbest). The position and velocity adjustment for each particle is formulated in Equation 2 and Equation 3.

$$
\begin{aligned}
& V_{i j}(t+1)=w v_{i j}(t)+\mathrm{c}_{1} r_{1}\left(p_{i j}-x_{i j}(t)\right)+c_{2} r_{2}\left(\mathrm{p}_{g}-\mathrm{x}_{i j}(\mathrm{t})\right) \\
& x_{i j}(t+1)=x_{i j}(t)+v_{i j}(t+1)
\end{aligned}
$$

Which $V_{i j}(t+1)$ is the speed update that will be used in determining the best position update $x_{i j}(\mathrm{t}+1)$. Then there are constants used in the formulation such as $w=$ inertia weight, and $\mathrm{c}$ is the velocity coefficient for PSO and $r$ are random numbers between -1 to 1 .

\section{Results and Discussion}

Results of surface deformation inversion data on Sinabung Volcano using Mogi models with PSO schemes showed good results in misfit and model responses so that it was sufficient to reconstruct the physical field model realistically.

\begin{tabular}{|c|c|c|c|c|c|c|c|c|c|}
\hline Phase & Model & misfit & AIC & $a(m)$ & $\begin{array}{l}\text { delta } \\
P / G\end{array}$ & $\mathrm{~d}(\mathrm{~m})$ & $x(m)$ & $y(m)$ & delta V \\
\hline 1 & Mogi dengan PSO & 0.0297 & 10.0593 & 669.5714 & 0.0626 & 27826.6160 & 450000.0 & 46001.89 & 58968083.71 \\
\hline 2 & Mogi dengan PSO & 0.0564 & 10.8718 & 236.1255 & 0.0230 & 1300.0000 & 428500.0 & 48148.75 & 952446.95 \\
\hline
\end{tabular}

Table 2. Result of Parameters Model Using PSO 


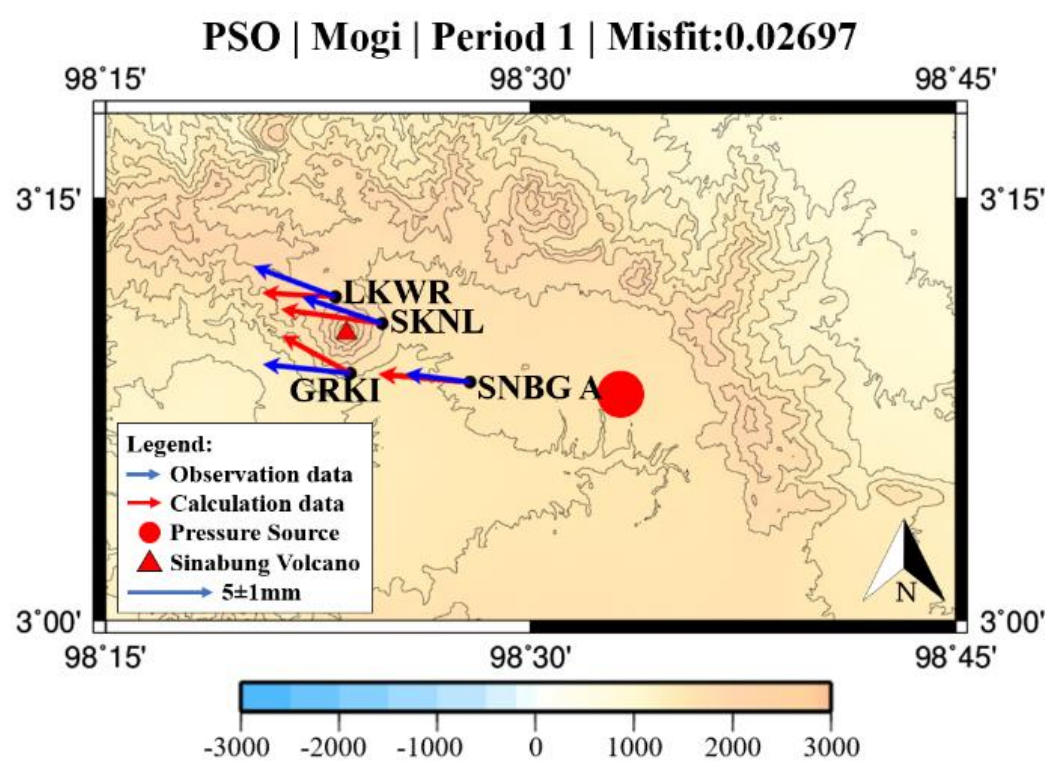

Figure 2. Inversion result in period 1.

The inversion results in period 1 showed inversion result at depth of around $27.8 \mathrm{~km}$ with change in the volume around $\pm 58.96 \times 10^{6} \mathrm{~m}^{3}$. This result is possible that the source of the inversion pressure is not a local pressure source from Sinabung Volcano but another pressure source which can be a tectonic or partial melting source which requires further study. In period 1 Sinabung Volcano was classified in a normal active period where no eruptions occurred and the status of the Sinabung Volcano was downgraded after eruptions his first eruption from 27 August 2010 to 3 September 2010 [9], that condition also reinforces that the deformation of the surface of Sinabung Volcano in period 1 is not from the local source. 

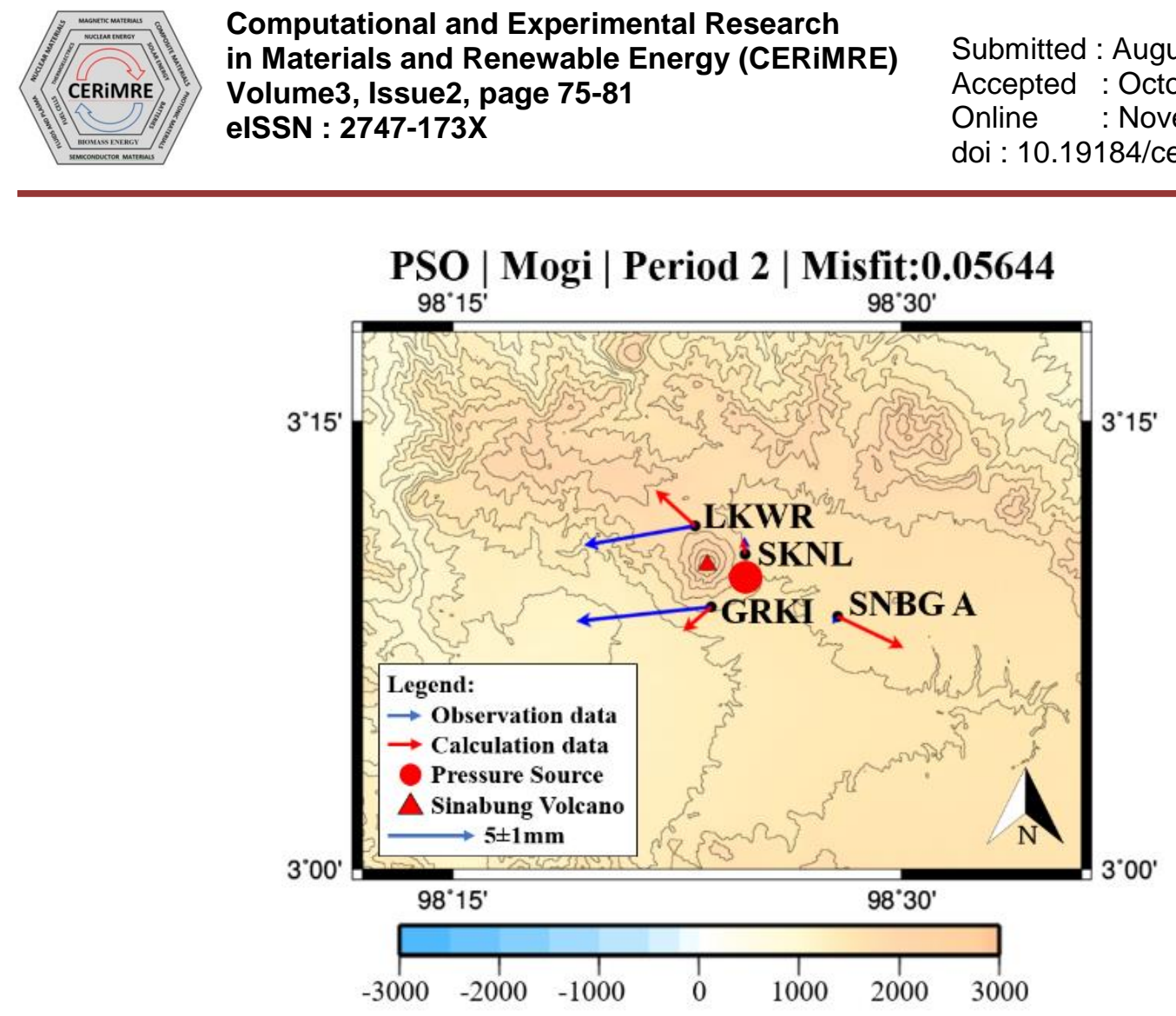

Figure 3. Inversion result in period 2.

The inversion results in period 2 show the smallest misfit obtained from the inversion in the Mogi model with the PSO scheme. The source of the inversion pressure is at a depth of $\pm 1.3 \mathrm{~km}$ with volume change around $\pm 0.95 \times 10^{6} \mathrm{~m}^{3}$ in the northeast sector of Sinabung Volcano. With a fairly shallow in depth of the pressure source in period 2, it can conclude that the source is magma pocket of Sinabung Volcano.

The inversion results are selected based on data misfit in accordance with the results of tectonic seismic hypocenter relocation by Indrastuti (2017) shown in Figure 4. Based on the inversion of the pressure source elaborated by the relocation of tectonic volcanic activity, it is known that tectonic volcano is associated with magma pocket of Sinabung Volcano, from the model also known that there are magma supply from deep magma pocket to moderate magma pocket and shallow magma pocket which marked by seismic hypocenters while at the same time strengthening that the inversion results are in accordance with the conditions of Sinabung volcano. 


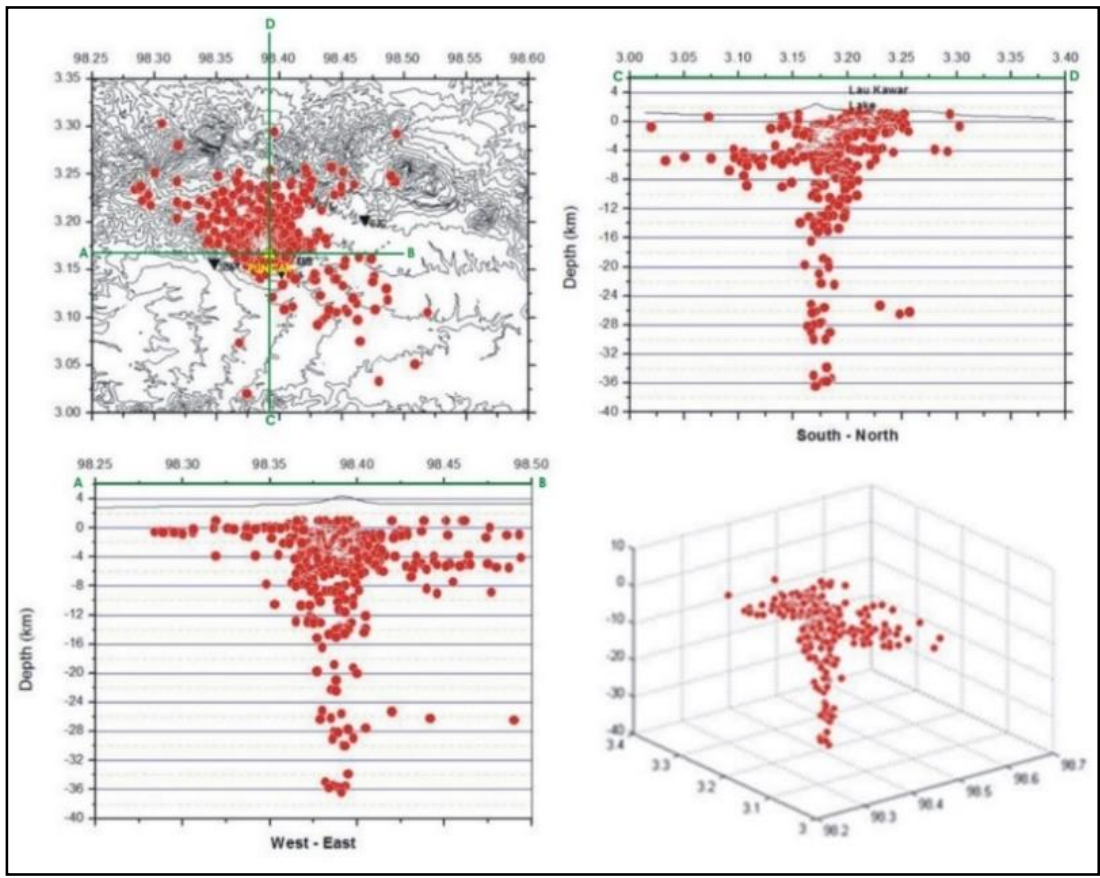

Figure 4. Hypocenter relocation of volcano tectonic [10]

\section{Conclusions}

The model resulting from the inversion process is sufficient to reconstruct the physical field. From the inversion concluded that the position pressure source showing shallow magma pockets at a depth between $\pm 1.3 \mathrm{~km}$ volume changes around $\pm 0.95 \times 10^{6} \mathrm{~m}^{3}$. It indicates the presence of a huge magma supply and continuous into shallow magma chamber up to the surface of Sinabung Volcano.

\section{References}

[1] Pusat Vulkanologi dan Mitigasi Bencana (PVMBG), 2010, Data Dasar Gunung Api di Indonesia Pusat Vulkanologi dan Mitigasi Bencana (PVMBG)

[2] N. Haerani, A. Basuki, Y. Suparman, S. Primulyana, O. Prambada, A. Loeqman, and T. Ohkura, 2012, Evaluation of volcanic activity at Sinabung volcano, after more than 400 years of quiet, Journal of Disaster Research, 7(1), 37.

[3] R. Kumalasari, W. Srigutomo, M. Djamal, I. Meilano, and H. Gunawan, 2018, Location of Sinabung volcano magma chamber on 2013 using lavenberg-marquardt inversion scheme, Journal of Physics: Conference Series, 1013(1).

[4] R. Kumalasari, W. Srigutomo, M. Djamal, I. Meilano, M. Evita, and H. Gunawan, 2019, Location of Sinabung volcano magma chamber on 2013 using simulated annealing inversion scheme. Journal of Physics: Conference Series, 1321(3).

[5] K. Mogi, 1958, Relations between the eruptions of various volcanoes and the deformations of the ground surface around them, Earthquake Res. Inst. Univ. Tokyo, volume 36 , page 99-134 
[6] D. Dzurisin, 2007, Volcano Deformation: New Geodetic Monitoring Technique, Springer, Berlin, Heidelberg.

[7] J. L. F. Martínez, E. Gonzalo, J. P. F. Álvarez, H. A. Kuzma, C. O. M. Pérez, 2010, PSO: A powerful algorithm to solve geophysical inverse problems Application to a 1D-DC resistivity case, Journal of Applied Geophysics, february 2010, pages 13-25.

[8] H. Gunawan, A. Budianto, O. Prambada, W. McCausland, J. Pallister, and M. Iguchi, 2017, Overview of the eruptions of Sinabung eruption, 2010 and 2013-present and details of the 2013 phreatomagmatic phase, Journal of Volcanology and Geothermal Research, volume 382, pages 103-119.

[9] J. Zhou, X. Yu and B. Jin, 2018, Short-term wind power forecasting: A new hybrid model combined extreme-point symmetric mode decomposition, extreme learning machine and particle swarm optimization, Sustainability (Switzerland), 10(9).

[10] N. Indrastuti, A. D. Nugraha, H. Gunawan, W. McCausland, 2017, 3-D Seismic Tomographic study of Sinabung Volcano, Northern Sumatra, Indonesia, during the intereruptive period October 2010 - July 2013, Journal of Volcanology and Geothermal Research, volume 382, pages 197-209. 